\title{
Unique method for structural synthesis of the machines planed with bars and dogs
}

\author{
E Niculae $^{1}$, A Dimitrescu ${ }^{1}$, C Babiş ${ }^{2}$, O Chivu ${ }^{2}$, L Dascălu ${ }^{2}$ \\ ${ }^{1}$ Theory of Mechanisms and Robots Department, Politehnica University, Bucureşti, România \\ ${ }^{2}$ Materials Technology and Welding Department, Politehnica University, București, România \\ banicaelisabeta29@yahoo.com
}

\begin{abstract}
The planar mechanisms with articulated bars and gears (which we will simply note MeBaRd) are part of the general planar mechanics category. Although structural structural studies have been carried out [7], the structural synthesis of bars and wheels can be approached as a distinct problem. Some papers refer directly to a certain class of mechanisms, such as planetary mechanisms [1], [2], others stop on subsystems with zero mobility, called structural groups with toothed elements [6], [8]. In this paper, developing some ideas presented in [3], [5], a general algorithm for unitary structural synthesis of MeBaRd was developed and developed, having the input parameters: $\mathrm{M}$ - the degree of mobility and $\mathrm{N}$ - the number of contours.
\end{abstract}

Keywords: structural synthesis, machines planed.

\section{The structural dimensions of MeBaRd}

In the structure of the Mechanisms with articulated bars and toothed wheels are distinguished as kinematic elements both bar elements between which the rotation $-\mathrm{C}_{\mathrm{bb}}$ (Figure 1a)) rotation and the toothed elements (wheels) between which the upper couplings - $\mathrm{s}$ appear. The functionality of a gear requires the constant distance between the axles of the wheels, so the existence of a bar with which it makes two rotation torques - $\mathrm{C}_{\mathrm{bd}}$ (Figure $\left.1 \mathrm{~b}\right)$ )).

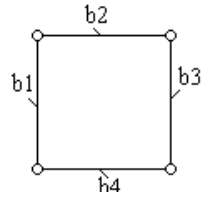

a)

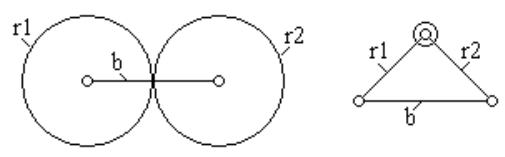

b)

Figure 1. Kinetic chains: a) with bars, b)toothed wheels.

Between the kinematic elements, the bars (b) and the gears (d), the following types of connections [5] occur: rotary couplers $\left(C=C_{b b}+C_{b d}\right)$, upper couplings ( $s$ ) and rigid links $\left(r=r_{b d}+r_{d d}\right)$ (Figure 2).

In the structural representation of the kinematic chains with bars and toothed wheels, conventional symbols are used which highlight the connections between the elements (Table 1).

The contours are distinguished $\left(\mathrm{N}_{\mathrm{b}}\right)$ - determined by bars, of class $\mathrm{j} \geq 4$ and contours $\left(\mathrm{N}_{\mathrm{d}}\right)$ - determined by the gears $\left(\mathrm{N}_{\mathrm{d}}=\mathrm{s}\right)$, of class $\mathrm{j}=3$.

Between the structural sizes: bars, gears, upper couplings, rigid links, contours and the degree of mobility, the relationship of interdependence:

$$
(b+d)-(s+r)=M+2 \cdot N_{b}+1
$$




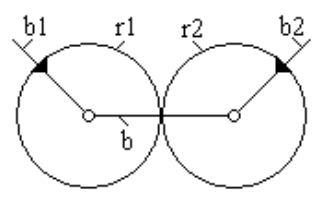

a)

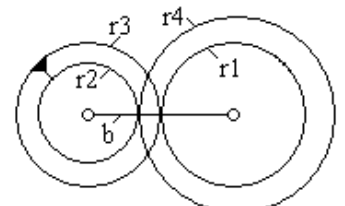

b)

Figure 2. Rigid connections: a) between bars and wheels; b) between two wheels.

Table 1. Structural symbols for MeBaRd.

\begin{tabular}{|l|l|l|}
\hline The conventional symbol & The meaning & Connected Connections \\
\hline$\bigcirc 0$ & two wheels & $\begin{array}{l}\text { - Upper coupling } \\
\text { - Two rotation torques }\end{array}$ \\
\hline & two wheels & $\begin{array}{l}\text { - Upper coupling } \\
\text { - a rotation coupler } \\
\text { - a rigid link }\end{array}$ \\
\hline & & $\begin{array}{l}\text { - Upper coupling } \\
\text { - two rigid links }\end{array}$ \\
\hline & two wheels &
\end{tabular}

\section{Structure synthesis of MeBaRd}

$\mathrm{MeBaRd}$ are determined from plane kinematic chains.The combination of wheels and bars is a parallel assembly in which the wheels are engaged and do not constitute isolated elements. The upper coupling is determined by the wheels positioned on the axles of the joints of a bar (bar represents the center of the center).

The rigid link between the bar and the wheel is possible if the wheel is not engaged with other wheels positioned on the axles of the joints of the bar and the rigid link between the two wheels is possible when they are positioned on the same axis.

\section{Numerical and Structural Solutions of MeBaRd}

Considering the degree of mobility $\mathrm{M}$ and the number of contours $\mathrm{N}$ as input parameters, determine the number of elements and rotation torques with the relations:

$$
\begin{aligned}
& n=M+2 \cdot N_{b}+s+1 \\
& c=M+3 \cdot N_{b}+s
\end{aligned}
$$

Starting from the relationship (1), the numerical solutions of the structural synthesis that have meaning for the whole and the positive values of the sizes $b, d, s, M, N_{b}$.

Consider $\mathrm{b}$ and $\mathrm{d}$, respectively $\mathrm{s}$ and $\mathrm{r}$, as classes of sets $\mathrm{A}$ and $\mathrm{B}$ respectively and the number of types of partitions of A and B in two classes is deduced. Depending on the number of bar contours $\left(\mathrm{N}_{\mathrm{b}}\right)$ and their classes, the minimum and maximum number for bars,

Where $\mathrm{j}_{\min }=4$

$$
\begin{aligned}
& b_{\text {min }}=j_{\text {min }} \cdot N_{b, j \min } \\
& b_{\text {max }}=j_{\text {max }} \cdot N_{b, j \text { max }}
\end{aligned}
$$

The number of upper couplers on a bar contour is $s_{\min } \leq s \leq s_{\max }$ the limit values being:

$$
\mathrm{s}_{\text {min }}=1 \quad \mathrm{~s}_{\text {max }}=2 \cdot \mathrm{j}
$$

Depending on the number of curves, $\mathrm{N}_{\mathrm{d}}$ determine the minimum and maximum number of toothed wheels,

$$
\begin{aligned}
& d_{\text {min }}=s+1 \\
& d_{\text {max }}=2 \cdot s
\end{aligned}
$$

The number of rigid links is limited by kinematic elements, $r_{\min } \leq r \leq r_{\max }$ the limit values being: 


$$
r_{\min }=b+d-n ; \quad r_{\max }=d
$$

The limits of sets $\mathrm{A}$ and $\mathrm{B}$ are thus determined:

$$
\begin{aligned}
& A_{\text {min }}=b_{\text {min }}+d_{\text {min }} \\
& A_{\text {max }}=b_{\text {max }}+d_{\text {max }}
\end{aligned}
$$

$$
\begin{aligned}
& B_{\text {min }}=s_{\text {min }}+r_{\text {min }} \\
& B_{\text {max }}=s_{\text {max }}+r_{\text {max }}
\end{aligned}
$$

Numerical solutions are obtained based on the SIMeBaRd calculation program. The program delivers results for different values of $\mathrm{M}$ and $\mathrm{N}_{\mathrm{b}}$, in relation to which the boundaries of the sets $\mathrm{A}$ and $\mathrm{B}$ are set.

One numerical solution corresponds to one or more structural solutions. In presenting the structural solutions, the simple structural schematic of the bars and gears is used.

$$
k=2(N+n-1)-\sum j \cdot N_{j}
$$

The limitation of solutions is given by the condition, the border contour being of maximum class, namely:

The number of inner rotation torques $\left(\mathrm{C}^{*}\right)$ and the number of inner elements $\left(\mathrm{n}^{*}\right)$ are determined with relationships:

$$
\begin{aligned}
& c^{*}=c-k \\
& n^{*}=n-k
\end{aligned}
$$

In structural schemes, the upper couplers are represented by two concentric circles in order to highlight the third class contours. Structural solutions can be represented by structural schemes MeBaRd [3], the symbols being explained in Table 1.

Table 2 shows the numerical solutions for $\mathrm{M}=1$ şi $N_{b}=1$, for $j=4 \div 6 \quad\left(j_{\min }=4 ; j_{\max }=6\right)$.

Table 2. Numeric solutions for pentru $\mathrm{M}=1$ and $\mathrm{N}_{\mathrm{b}}=1, N_{d}=s$

\begin{tabular}{|l|l|l|l|l|l|l|l|l|}
\hline $\mathbf{A}$ & $\mathbf{b}$ & $\mathbf{d}$ & $\mathbf{B}$ & $\mathbf{S}$ & $\mathbf{r}$ & $\mathbf{c}$ & $\mathbf{c}_{\mathrm{bb}}$ & $\mathbf{c}_{\mathrm{bd}}$ \\
\hline 6 & 4 & 2 & 2 & 1 & 1 & 5 & 4 & 1 \\
\hline 7 & 4 & 3 & 3 & 2 & 1 & 6 & 4 & 2 \\
\hline 7 & 5 & 2 & 3 & 1 & 2 & 5 & 5 & 0 \\
\hline 8 & 4 & 4 & 4 & 2 & 2 & 6 & 4 & 2 \\
\hline 8 & 4 & 4 & 4 & 3 & 1 & 7 & 4 & 3 \\
\hline 8 & 5 & 3 & 4 & 2 & 2 & 6 & 5 & 1 \\
\hline 9 & 4 & 5 & 5 & 3 & 2 & 7 & 4 & 3 \\
\hline 9 & 4 & 5 & 5 & 4 & 1 & 8 & 4 & 4 \\
\hline 9 & 5 & 4 & 5 & 3 & 2 & 7 & 5 & 2 \\
\hline 10 & 4 & 6 & 6 & 3 & 3 & 7 & 4 & 3 \\
\hline 10 & 4 & 6 & 6 & 4 & 2 & 8 & 4 & 4 \\
\hline 10 & 5 & 5 & 6 & 3 & 3 & 7 & 5 & 2 \\
\hline 10 & 5 & 5 & 6 & 4 & 2 & 8 & 5 & 3 \\
\hline 10 & 6 & 4 & 6 & 2 & 4 & 6 & 6 & 0 \\
\hline
\end{tabular}

Table 3 presents structural schemes MeBaRd for $M=1 ; N_{d}=2 ; N_{b}=1$ with $j=4$ and the kinematic schemes of articulated bars and toothed wheels.

Table 3. Structural schemes and MeBaRd kinematic chains for $N_{b}=1$, with $j=4$ 
Volume 1, Issue 1, 2019

ISSN: 2668-0416

Thoth Publishing House

The structural
solutionMeBaRd

\section{Conclusions:}

The structural calculation algorithm of MeBaRd is applicable to various values of structural input parameters. The MeBaRd structural schemes make it easy to obtain kinematic schemes and eliminate the possibility of bridging the wheels and bars. The computation program executed in QBASIC language can easily be passed to another programming language.

\section{References}

[1] Bugaevschi, E., Consideraţii structurale privind mecanismele cu cuple superioare; SYROM'73,vol.C,Bucureşti,1973.

[2] Bobancu, S.,Contribuţii la structura mecanismelor biplanetare, multiplanetare; SYROM'73,vol.C,București,1973.

[3] Grecu, B.,Sistematizarea lanţurilor cinematice cu bare articulate şi roţi dinţate; București, 1978.

[4] Pelecudi,Chr.,Metoda contururilor în sinteza numerică şi structurală a lanţurilor cinematice St.cerc.mec.apl.,nr.3,1967.

[5] Pelecudi, Chr., Grecu, B., Asupra sistematizării mecanismelor plane cu bare articulate şi roţi dinţate; SYROM ' 81, vol.III,Bucureşti.

[6] Rooney,G.T.,Zamfir,V.,Sinteza structurală a lanţurilor cinematice plane cu bare şi elemente dinţate cu $L_{3}=4, l=5, c_{5}=4, c_{4}=1$; SYROM'73, vol.A, Bucureşti,1973.

[7] Tempea, I.,Sinteza structurală a lanţurilor cinematice plane generale cu $N=1,2,3$, contururi deformabile şi grad delibertate L3 = 4 ,St.cerc. mec. aplic., nr.1, 1972.

[8] Zamfir, V., Asupra analizei şi sintezei structurale a lanţurilor cinematice cu bare şi elemente dinţate, SYROM'73, vol.A, București,1973. 